International Journal of Current Advanced Research

ISSN: O: 2319-6475, ISSN: P: 2319 - 6505, Impact Factor: SJIF: 5.995

Available Online at www.journalijcar.org

Volume 6; Issue 3; March 2017; Page No. 2449-2453

DOI: http://dx.doi.org/10.24327/ijcar.2017.2453.0026

Research Article

\title{
RISK FACTORS SURVEY OF PEJORATIVE EVOLUTION OF DELIVERY LABOR IN A CONGOLESE RURAL HOSPITAL
}

\author{
Juakali SKV*., Maindo A., Komanda L and Manga 0
}

Université de Kisangani/Département de gynécologie-obstétrique/RD Congo

\section{A R T I C L E I N F O \\ Article History: \\ Received $10^{\text {th }}$ December, 2016 \\ Received in revised form $7^{\text {th }}$ January, 2017 \\ Accepted $11^{\text {th }}$ February, 2017 \\ Published online $28^{\text {th }}$ March, 2017}

\section{Kye Words:}

Risk Factors - Pejorative Evolution - Delivery Labor - Rural Hospital

\begin{abstract}
A B S T R A C T
Introduction: Caesarean sections done in emergency situation are an important source of maternal and perinatal morbidity and mortality in Africa. Our aim is to identify risk factors for Caesarean section in primiparous patients at the Oïcha General Referral Hospital in the Democratic Republic of the Congo.

Materials and methods: This was a case-control documentary study conducted from April 1 to September 30, 2012 on a sample of 686 primiparous. Inclusion criteria: admission at the start of labor with term pregnancy, single fetus in top cephalic presentation, fetal heart sound in standards, followed by partogram.

Variables explained: caesarean section, low Apgar score, drawling work; Explanatory variables: age, height, body mass index at the beginning of pregnancy, angle adjacent to the hypotenuse calculated at the end of the period of cervical dilatation.

Description of the variables: calculation of the frequency, percentage, averages and their standard deviations. Association between explained and explanatory variables: tested in bivaried analysis by the Pearson chi-square ( $p<0.05$ at the $95 \%$ threshold); Strength of association by multivariate analysis of significant predictive factors $(p<0.05)$ with conditional logistic regression.

Conclusion: The angle adjacent to the hypotenuse is a critical risk factor for Caesarean section, low Apgar score and work dragging when it remains below $45^{\circ}$. Find to it a corrective factor at this stage of labor could improve maternal and neonatal prognosis.
\end{abstract}

Copyright $₫ 2017$ Juakali SKV et al. This is an open access article distributed under the Creative Commons Attribution License, which permits unrestricted use, distribution, and reproduction in any medium, provided the original work is properly cited.

\section{INTRODUCTION}

At the primiparous, the main indications of the caesarean section under delivery labor (outside of pathologies) are the mechanical and dynamic dystocia, serious anomalies of the fetal cardiac rhythm, and a non-engagement of the presentation to advanced or complete dilation [1, 2, 3].

The results of the WHO world investigation [3] on the surveillance of the maternal and perinatal health show that the increase of the rates of caesareans section is associated to a high risk of antibiotherapy use after the childbirth as well as maternal stern morbidity and mortality. It is also associated to an increased rate of fetal death and the number of newborns admitted in intensive care units in relation to the newborn by eutocic mode [4, 5]. The precarious conditions of realizations of caesareans sections, in Africa, make thisintervention of high risk [4] and the relative data to the assessment of the maternal and neonatal prognosis that ensue from them are not sufficiently informative [5].

\section{*Corresponding author: Juakali SKV}

Université de Kisangani/Département de gynécologieobstétrique/RD Congo
At the General Referral Hospital of Oïcha (GRHO) where we led this research, the rates of caesareans $(26.1 \%)$ and low scores of Apgar (13.6\%) remain high in spite of the correct application of the partogramme of the WHO consecutive to the formation of the health care provider [6].

Hence, our objective was to identify the risk factors of the caesarean and low scores of Apgar at the $5^{\text {th }}$ minute at the primiparousat the GRHO.

\section{MATERIAL AND METHODS}

This was a documentary case-control survey which was carried out at GRHO from April $1^{\text {st }}$ to September 30, 2012 on a sample of 686 primiparous drawn in a population of 2136 parturient.

Our patients were distributed in two groups: the cases and the controls responding to the following inclusion criteria: being admitted at the beginning of delivery labor with a mono fetal pregnancy in term, cephalic presentation of summit, fetal heart rate in the norms, intact membranes, without cervix anomalies, and follow up on partograph. Each "case" possessing characteristic of the explained variable, was compared to a "control" group. 


\section{The dependent variables explained studied were}

The caesarean section: we had considered like "case", all parturient responding to the inclusion criteriaand having undergone a caesarean section;

The weak score of Apgar: quotation lower to 7, at the $5^{\text {th }}$ minute.

The trailing delivery labor: the one whichthe duration was superior to 10 hours from the fast dilation phase [7].

Therefore, for every case of caesarean section $(n=179)$, we kept 2 controls $(n=358)$ having given birth by eutocic mode and who followed the case directly. For the cases of trailing dilation $(\mathrm{n}=191)$, we had included 2 controls with of normal duration $(n=382)$ according to the case of trailing dilation. For every case of weak score of Apgar $(n=93)$, we kept 2 controls $(n=186)$ having had a good Apgar score after the case of weak score of Apgar. Finally, for every case of adjacent angle to the resulting hypotenuse of the vector of cervix dilation and the one of the duration of the time in hours $<45^{\circ}(\mathrm{n}=314)$, was kept a control $(\mathrm{n}=314)$ with angle $>45^{\circ}$ that followed the case directly.

The retained explanatory variables were: age, the size and the maternal weight at the beginning of pregnancy, but also the adjacent angle to the hypotenuse calculated at the end of the phase of latency of cervix dilation (dilation at $4 \mathrm{~cm}$ or 8 hours after the beginning of delivery labor).

In relation with the maternal age, we had categorized our patients in 3 different age groups, expressed in years: $\triangle 7$ years, age of 18 to 25 years and age $\geq 26$ years. The age group of 18 to $25 \mathrm{ans}$ was considered like slice of reference to least obstetric risk. According to their size, returned in centimeters, our parturient was distributed in 2 groups: those whose size was lower than $150 \mathrm{~cm}$ and those whose size was $\geq 150 \mathrm{~cm}$. This last category had been taken like category of reference. According to their weight, our parturient had been classified in two groups depending on whether their weight, expressed in kilograms, in the beginning of pregnancy was $<50 \mathrm{~kg}$ or then $>50 \mathrm{~kg}$. The class whose weight was superior to $50 \mathrm{~kg}$ had served us like class control. For the body mass index (BMI) expressed in $\mathrm{kg} / \mathrm{m}^{2}$, we had kept 3 groups: those with a $\mathrm{BMI}<18.5 \mathrm{~kg} / \mathrm{m}^{2}$, those whomBMI varied between 18.5 and $29.9 \mathrm{~kg} / \mathrm{m}^{2}$ and those whomBMI was $230 \mathrm{~kg} / \mathrm{m}^{2}$. The first and the third group were compared to the second group, it means the one whose IMC varied between 18.5 and $29.9 \mathrm{~kg} / \mathrm{m}^{2}$ and that had served us as value marks. The mean velocity of cervix dilation at the active phase of delivery labor was determined while calculating the total duration of the delivery laborfrom $4 \mathrm{~cm}$ of dilation until the moment of the childbirth by eutocic mode or by caesarean section. The parturient was classified in two groups: those with a velocity $<1 \mathrm{~cm} / \mathrm{h}$ and those with a velocity $\geq 1 \mathrm{~cm} / \mathrm{h}$. This last category had served us like witness.

The external pelvimetry, notably the diameter of Baudelocque and the bi-ischiatic diameter were taken. For the Baudelocque: the parturient was distributed in 2 groups depending on whether the Baudelocque was normal $(\geq 20 \mathrm{~cm})$ or limit $(19 \mathrm{~cm})$. In relation with the bi-ischiatic diameter: we had distinguished those withlimits diameter $(8 \mathrm{~cm})$ and those with normal diameter $(9-10 \mathrm{~cm})$. The parturient withlimits diameters was compared to those whose diameters were normal.
The adjacent angle to the hypotenuse, calculated at the end of the phase of latency of cervix dilation (dilation at $4 \mathrm{~cm}$ or 8 hours after the beginning of delivery labor) was formed by the vector time (abscissa) and the equipollent of the vector dilation (ordinate). We had considered like hypotenuse, the resultant formed by the axis or vector of degree of dilation in ordinate, with the axis or vector of time in abscissa. The calculation of the angle made itself with the help of the reporter.

For describing the qualitative variables, we had calculated the frequency and the percentage, and for the quantitative variables, we had determined the means and their standards deviations.

The associations between the different explained and explanatory variables had been studied and tested in bivariedanalysis, with the help of the chi square of Pearson $(P$-value) or the test of Fischer. We had considered that the difference was significant when $P<0.05$ at $95 \%$.

To measure the strength of association between the presence of a predictive factor and the intervening of an event, we had achieved amulti varied analysis of the significant predictive factors $(P<0.05)$ with conditional logistical regression. The Odds ratio (OR) and their intervals of confidence (IC) at $95 \%$ were used to value the strength of the association for every parameter with a treshold of significance to $\mathrm{P}<0.05$ or exact Fischer $<0.05$. We had concluded that there was association when OR> 1 , and that the factor was independent if the boundary-marks of the IC were also $>1$.

\section{RESULTS}

\section{Risk factors of the caesarean section}

The multi varied analysis, with conditional logistical regression, had allowed controlling the significant predictive factors $(P<0.05)$ and to keep, as independent factors of the caesarean: the adjacent angle to the hypotenuse inferior to $45^{\circ}$ at the end of the phase of latency, the BMI $\geq 30 \mathrm{~kg} / \mathrm{m}^{2}$, the size $<150 \mathrm{~cm}$, age $\geq 26$ years and the trailing delivery labor.

Table 1 Risk Factors of the Caesarean

\begin{tabular}{ccc}
\hline Risk factors & $\boldsymbol{P}$-value & OR $($ IC at 95\%) \\
\hline Age $\geq 26$ years & 0.0008 & $2.2945(1.4014-3.7566)$ \\
Single & 0.0000 & $0.1124(0.0691-0.1828)$ \\
Size $<150 \mathrm{~cm}$ & 0.0010 & $1.9774(1.3087-2.9879)$ \\
BMI $\geq 30 \mathrm{Kg} / \mathrm{m}^{2}$ & 0.0015 & $1.9044(1.2752-2.8439)$ \\
Baudelocque limit & 0.0000 & $0.3293(0.2267-0.4783)$ \\
Bi-ischiatic limit $(8 \mathrm{~cm})$ & 0.0000 & $0.4215(0.2858-0.6217)$ \\
Angle $<45^{\circ}$ & 0.0000 & $5.1600(3.4576-7.7005)$ \\
Dilatation velocity <1cm/H & 0.0000 & $0.3723(0.2516-0.5511)$ \\
Prolonged delivery labor & 0.0002 & $2.2431(1.4520-3.4650)$ \\
\hline
\end{tabular}

\section{Risk factors of low score Apgar}

The multi varied analysis by conditional logistical regression of the significant predictive factors of low scores of Apgar $(P<0.05)$, did have shown that only the angle lower to $45^{\circ}$, the caesarean, the $\mathrm{BMI} \geq 30 \mathrm{~kg} / \mathrm{m}^{2}$, the prolonged delivery labor was independent of low score of Apgar at the $5^{\text {th }}$ minute (Table 2). 
Table 2 Risk factors of low score of APGAR

\begin{tabular}{ccc}
\hline Risk factors & $\boldsymbol{P}$-value & OR (IC at95\%) \\
\hline Angle $<45^{\circ}$ & 0.0000 & $4.1739(2.4301-7.1691)$ \\
BMI $\geq 30 \mathrm{~kg} / \mathrm{m}^{2}$ & 0.0000 & $3.2449(1.8404-5.7213)$ \\
Mean dilatation velocity $<1 \mathrm{~cm} / \mathrm{H}$ & 0.0649 & $0.6189(0.3712-1.0319)$ \\
Trailing delivery labor & 0.0000 & $11.2186(6.0669-20.7450)$ \\
Caesarean & 0.0001 & $2.9413(1.6584-5.2164)$ \\
\hline
\end{tabular}

\section{Risk factors of trailing delivery labor}

The factors of risk kept for the prolonged delivery labor were: the angle $<45^{\circ}$, age $\geq 26$ years, and the size $<150 \mathrm{~cm}$, the weight $<50 \mathrm{Kg}$ and a mean dilation velocity of $<1 \mathrm{~cm} /$ hourat the phase of fast cervix dilation.

Table 3 Risk of trailing delivery labor

\begin{tabular}{ccc}
\hline Risk factors & $\boldsymbol{P}$-value & OR $($ IC at 95\%) \\
\hline Age $\geq 26$ years & 0.0000 & $2.6741(1.7147-4.1701)$ \\
Size $<150 \mathrm{~cm}$ & 0.0000 & $3.3481(2.1996-5.0964)$ \\
Height $<50 \mathrm{Kg}$ & 0.0000 & $2.7316(1.8023-4.1401)$ \\
Angle $<45^{\circ}$ & 0.0000 & $2.6419(1.8474-3.7783)$ \\
Velocity of dilatation $<1 \mathrm{~cm} /$ hour & 0.0108 & $1.5811(1.1103-2.2516)$ \\
\hline
\end{tabular}

\section{Adjacent angle to the hypotenuse and obstetric maternal and fetal prognosis}

The opening degree of the adjacent angle to the hypotenuse at the end of the phase of latency was a risk factor determining the caesarean section, the low score of Apgar and prolonged delivery labor when this angle was lower than $45^{\circ}$ (Table 4).

Table 4 Adjacent angle to the hypotenuse and maternal and fetal prognosis

\begin{tabular}{ccc}
\hline Risks & $\boldsymbol{P}$-value & OR $($ IC at 95\%) \\
\hline Velocity of dilatation $<1 \mathrm{~cm} / \mathrm{H}$ & 0.0000 & $3.1749(2.2904-4.4009)$ \\
Trailing delivery labor & 0.0000 & $5.0334(3.3733-7.5106)$ \\
Caesarean & 0.0000 & $5.0231(3.2612-7.7369)$ \\
Apgar $<7$ & 0.0000 & $3.8228(2.4675-5.9225)$ \\
\hline
\end{tabular}

\section{DISCUSSION}

\section{Risk factors of the caesarean sections}

\section{Adjacent angle to the hypotenuse and outcome of the childbirth}

We had noted that parturient at whom the adjacent angle to the hypotenuse was $<45^{\circ}$ to the dilation of $4 \mathrm{~cm}$ were, significantlyenoughfor giving birth by caesarean section: $36.4 \%$ against $10.3 \%$ for those whose angle was $\geq 45^{\circ}$. This can be explained by the implications of this angle on the progress of delivery laboritself. Indeed, when the adjacent angle to the hypotenuse was lower to $45^{\circ}$, the mean velocity of dilation stayed lower than $1 \mathrm{~cm} /$ hour with a consequence of a trailing delivery labor.

Other authors $[8,9]$ had established an correlation between a trailing delivery labor and the tendency to the caesarean section. Chelmowet al. [10] had noted that the weak velocity of dilatation prolonging the phase of latency was associated to the dystocia more in the phase of fast dilation of the delivery labor.

Cheng et al. [11] had found a strong association between a prolonged latency phase and the intervening of the cesareans sections $(\mathrm{OR}=2.28)$ [1.92-2.72].

\section{BMI of parturient before pregnancy and mode of childbirth}

Parturient with a BMI $230 \mathrm{~kg} / \mathrm{m}^{2}$ was significantlyenough in the group of childbirth by caesarean section than the one by eutocic mode (38,6\% vs. $26,4 \%)$.

Other authors have found also, through the world, a strong association between the BMI > $30 \mathrm{~kg} / \mathrm{m}^{2}$ at the beginning of pregnancy and the raised rates of caesarean section at primiparouscompared to the group in normal BMI [12]. Dzakpasuet al. [13], in Canada, had found the relation between the overweight, the obesity and the caesarean section around $20.2 \%$.

Berendzenet al. [14], comparing parturientof different BMI had reported the rates of caesareans section as follows in the different categories: $56.6 \%$ of caesareans section inthe cases of morbid obesity, $39.1 \%$ to $40.8 \%$ in case of overweight or simple obesity, $31.4 \%$ for a normal BMI and $26 \%$ in the case of BMI lower than $18 \mathrm{~kg} / \mathrm{m}^{2}$.

Poobalanet al. [15], in a systematic review on the obesity as risk factor of caesarean at primiparous had noted an odds ratio of 1.64 in case of overweight's and 2.23 in case of obesity, compared to the primiparous in normal BMI.

\section{Size of the parturient and mode of childbirth}

Parturient with a size lower than $150 \mathrm{~cm}$ were represented significantly more in the group of childbirth by caesarean section than in the one of childbirth by eutocic mode, either respectively $31.3 \%$ against $18.7 \%$.

Diarraet al. [16], in Mali, had found that the size was a major factor in the anomaly of the cervical dynamics. $68.75 \%$ of their patientswho had a size lower than $150 \mathrm{~cm}$ had presented a mechanical dystocia with repercussion on the cervical dynamics, what had indicated the caesarean section.

This difference of caesarean rate in relation to the one found by Diarraet al. [16], can be explained itself by the size of their sample that was relatively small, either 16 primiparous of size lower than $150 \mathrm{~cm}$.

MC Guinness et al. [17], had also noted, in New Zealand, that a small size was associated to a raised risk of caesarean section consecutive to a trailing delivery labor.

\section{Age of the parturient and mode of childbirth}

We had found that parturient of the age group $\geq 26$ years had been significantlyenough to give birth by caesarean section $(24.3 \%)$ than in eutocic mode (12.9\%). A similar report had been made by Aghamohammadiet al. [18] in Iran. Tebeuet al. [19], in Yaoundé, had also noticed that the aged primiparouswas associated to a strong rate of caesarean section.

As Hand et al. [20] noticed, there is a correlation between the maternal age and the uterine dysfunction risk, and for that the rate of caesarean section increases significantly at primiparous from the age of 25 years and more.

\section{Risk factors of low scores of Apgar}

\section{Score of Apgar and mode of childbirth}

In our survey, the caesarean section was associated to a raised rate of newborns with weak score of Apgar at the $5^{\text {th }}$ minute 
(78.6\%) against $(55.4 \%)$ for those born by eutocic mode. In Rwanda, Batungwanayoet al. [21] had found 52\% of low scores of Apgar at the pregnant women whose delivery labor had lasted 11 to 24 hours against $1.23 \%$ at those of which the duration of delivery labor was lower than 10 hours.

In a survey achieved at 200 parturient distributed in three groups according to the boundary-marks of the partograph, Lakshmideviset al. [22] had put in evidence a strong association between the mode of childbirth and the low scores of Apgar according to the boundary-marks of the partograph. Therefore, $33.3 \%$ of the newborn by caesarean section, between the line of alert and the one of action, had a score of Apgar lower than 6. The rate of low scores of Apgar was higher when the caesarean intervened beyond the line of action; it had concerned $97 \%$ of newborn.

It is true that in our survey, the caesarean section was often indicated late to respect the boundary-marks of the partograph of the WHO, notably in its line of action. Also the management of newborn between the birth and the $5^{\text {th }}$ minute had not always been well followed, considering the number raised of the simultaneous births and the staff relatively reduced at the motherhood. The trailing delivery labor had also caused low scores of Apgar in our survey. It can be explained, as Fourniéet al. had affirmed it [23], by the weariness of the reserve in oxygen of the inter-villousroom, also by the maternal overworking, that comes with the unrests of ventilation, ahypocapniaand a major respiratory alkalosis decreasing the placental debit, so acute fetalsuffering.

\section{Score of Apgar and BMI}

In our survey, newborns from mothers with aBMI $230 \mathrm{~kg} / \mathrm{m}^{2}$ weresignificantlyenough to have a weak score of Apgar, $57.1 \%$ against $26.8 \%$.

Our results are comparable to those raised in literature: authors as Cheng et al. [11], Eliasdottiret al. [24], skull et al. [25], did also have found a strong association between the BMI $\geq 30$ at the beginning of pregnancy, the raised rates of caesarean section and low scores of Apgar at primiparous compared to the group in normal BMI.

\section{Score of Apgar and adjacent angle to the hypotenuse at dilation of $4 \mathrm{~cm}$}

We had noticed a frequency more increased of the lower scores of Apgar to 7 when the adjacent angle to the hypotenuse was $<45^{\circ}$ in $30.3 \%$ at the cases against $10.3 \%$ among the controls. The adjacent angle to the hypotenuse inferior to $45^{\circ}$ means, on the clinical plan, that the mean velocity of dilation is slow, lower than $1 \mathrm{~cm}$ per hour. It is therefore predictive of a trailing delivery labor and hypoxia during delivery labor.

Allen et al. [26] had noticed also that the risk of perinatal morbidity, expressed by low scores of Apgar, was raised appreciably when the phase of active dilation of delivery labor was prolonged.

The hypoxia, during delivery labor, had been made responsible, by some authors [27], of neonatal depression; of number raised of neonataldeaths yearly [28] but also of the survivors who could develop neurological troubles as the cerebral motor infirmities, the mental delay, behavior troubles, blindness [10, 26, 28].
Ayangade [29] in Nigéria, had found a significant correlation between a trailing latency phase and a weak score of Apgar at to the $5^{\text {th }}$ minute $(P<0.05)$. Cheng [11], in California had found the same type of association also with a $P$-value of 0.02 .

Batungwanayoet al. [21] in Rwanda had found that parturient of whom the duration of delivery labor was 11 to 24hours had given $52 \%$ of newborn with down score of Apgar against $1.23 \%$ when this duration was lower than 10 hours. In any case, in their survey, no one of women not having made more than 24hours of delivery labor had given some newborns with good score of Apgar. The rates found by Batungwanayoet al. [21] are probably different from ours because in their survey, they had integrated all parturient whatever is the degree of cervix dilation at the admission to the motherhood, whereas we had taken into account only those who had arrived in the beginning of the phase of latency.

\section{CONCLUSION}

The adjacent angle to the hypotenuse, calculated at the end of the phase of latency of the cervix, is a determiningrisk factor of the caesarean, low score of Apgar and trailing delivery labor when it stays lower than $45^{\circ}$. Finding to it a corrective factor to this stage of delivery labor could improve the maternal and neonatalprognosis.

\section{References}

1. De Swiet M. Why mother die. Report on confidential enquiries into maternal death in the kingdom 19941996. American journal of obstetrics and gynecology1998, 182: 760-766.

2. Deneux C, Tharaux, Carnona E, BouvierColle MH, Breard G. Postpartum maternal mortality and cesarean delivery. Obstetricgynecology, 2006; 108: 541-548.

3. Villar J, Valladares E, Wojdyla D, et al.WHO 2005 Global Survey on Maternel and Perinatal Health Research Group. Cesarean delivery rates and pregnancy outcomes: the $2005 \mathrm{WH}$ global survey on maternal and perinatal health in Latina America. Lancet 2006; 367: 1819-29.

4. Dumont A, De Bernis L, Bouvier-ColleMh, Breart G. Caesarean section rate for maternel indication in subsaharan Africa : a systematic review. Lancet 2001; 358: 1328-33.

5. Saissy JM. L'hématome rétro placentaire, in Saissy JM-réanimation tropicale. Arnetteed, Paris, 1997, pp 267-282.

6. Juakali SKV, Manga O, Komanda L, Maindo A. Evaluation de la formation des prestataires sur le partogramme et le pronostic materno-fœtal dans une maternité rurale congolaise. Abstract book, Numéro spécial $7^{\text {ème }}$ congrès national de la société congolaise de Gynécologie et Obstétrique à Kisangani, KisMed, 2015, page 182

7. Cunningham, F.G, Leveno, K.J, Bloom, S.T, Hauth, J.C, Rouse, D.J. \& Spong, C.Y. Williams Obstetrics. (23e éd.). United States: McGraw-Hill, 2010.

8. Jeremy L. Neal, Nancy K. Lowe, Karen L. Ahijevych, Thelma E. Patrick, Lori A. Cabbage, and Elizabeth J. Corwin: "Active labor" duration and dilation rates among low-risk, nulliparous women with spontaneous 
labor onset: a systematic review. $J$ MidwiferyWomensHealth, 2010; 55 (4): 308-318.

9. Jeremy L. Neal, Nancy K. Lowe: Physiologic partograph to improve birth safety and outcomes among low-risk, nulliparous women with spontaneous labor onset. Med Hypotheses. 2012 February; 78(2): 319-326.

10. Chelmow D, Kilpatrick SJ, Laros RK. Maternal and neonatal outcomes after prolonged latent phase. ObstetGynecol 81:486, 1993.

11. Cheng YW, Shaffer BL, Bryant AS, Caughey AB. Length of the first stage of labor and associated perinatal outcomes in nulliparous women. Obstet Gynecol. 2010; 116 (5): 1127-35.

12. Kjaergaard H, Olsen J, Ottesen B, Nyberg P, Karin A. Obstetric Risk indicators for Labour Dystocia in Nulliparous Women: A Multi-centre Cohort Study. Med Hypotheses, 2010; 74: 81-82.

13. Dzakpasu S, Fahey J, Russel RS, Tough SC, Chalmers B, MavreenIHet al.. Contribution of pregnancy body mass index and gestational weight gain to caesarean birth in Canada. BMC Prepregnancy childbirth. 2014; 14.

14. Berendzen JA, Howard BC. Association between cesarean delivery rate and body mass index. Tenn med. 2013 Jan; 106: 35-7, 42.

15. Poobalan AS, Aucott LS, Gurung T, Smith WC, Bhattacharya S. Obesity as an independent risk factor for elective and emergency caesarean delivery in nulliparous women. Systematic review and metaanalysis of cohort studies. Obes Rev. 2009 Jan; 10: 2835.

16. Diarra I, Camara S, Maiga MK. Évaluation de l'utilisation du partogramme à la maternité du centre de santé de référence de la commune $\mathrm{V}$ du District de Bamako. Mali Médical 2009. Tome XXIV Nº 2.

17. Macé G, Aubry MC, Aubry JP, Dommergues M. Anomalies neurologiques fetales. Diagnostic prénatal échographique. EMC (Elsevier Masson SAS, Paris), Gynécologie/Obstétrique, 5-031-A-33, 2007.

18. Aghamohammadi A and Nooritajer M. Maternal age as a risk factor for pregnancy outcomes: maternal, fetal and neonatal complication. African journal of pharmacology, vol. 5 (2), pp. 264-269, February 2011.
19. Tebeu P.M, Obama M.T, FodjoNghonguia M, Major A.L, Kouam L, Doh A.S : Primiparité âgée : du concept à la définition d'une méthode de détermination. Médecine d'Afrique $2008 ; 55$.

20. Main DM, Main EK, Moore DH. The relationship between maternal age and uterine dysfunction: A continuous effect throughout reproductive life. Presented at the sixty-sixth annual meeting of the pacific coast obstetrical and gynecological society, Cancun, Mexico, October 20-24, 1999.

21. Batungwanayo C., Dujardin B., Questaux G., Dusabemaria B. Résultat de l'introduction du partogramme à l'hôpital de Kabgayi (Rwanda). Médecine d'Afrique Noire, 1995 : 995pp 628-635.

22. Lakshmidevi M, Malini KV, Shetty VH. Partographic analysis of spontaneous at term in primigravida. $J$ obstetGynaecol India. 2012 dec; 62:635-40.

23. Fournié A, Connan K, Parant O, Lesourd-Pontonnier F. Encyclmédchir (Elsevier, Paris), obstétrique, 5-077-A30, Elsevier.Paris 1998, 11p.

24. Eliasdottir OJ, Haroardottir H, Porkelsson P. The effect of maternal weight on pregnancy outcome. Laeknabladdid. 2010 Nov; 96: 691-6.

25. Crane JM, White J, Murphy P, Burrage L, Hutchens D. The effect of gestational weight gain by body mass index on maternal and neonatal outcomes. $J$ obstetgynaecol. 2009; 31: 28-35.

26. Allen VM, Baskett TF, O'Connell CM, McKeen D, Allen AC. Maternal and perinatal outcomes with increasing duration of the second stage of labor. Am J Obstet gynecol. 2009 Jun; 113 (6): 1248-58.

27. Papadias K, Christopoulos P, Derigeoroglou E, Vitoratos N, Makrakis E, Kaltapanidou P, Tsoukas A, Creatsas G. Maternal age and the duration of the second stage of labor. Birth, 2006 Dec; 33: 315-22.

28. Lee AC, Cousens S, Darmstadt GL, Blencowe H, Pattinson R, Moran NF, Hofmeyr GJ, Haws RA, Bhutta SZ, Lawn JE. Care during labor and birth for the prevention of intrapartum-related neonatal deaths: a systematic review and Delphi estimation of mortality effect. BMC Public Health 2011, 1:S10.

29. Ayangade O. Characteristics and significance of the latent phase in outcome of labor among Nigerian parturients. J Natl Med Assoc. 1984; 76 (6): 609-13.

\section{How to cite this article:}

Juakali SKV et al (2017) 'Risk Factors Survey Of Pejorative Evolution Of Delivery Labor In A Congolese Rural Hospital', International Journal of Current Advanced Research, 06(03), pp. 2449-2453. 